\title{
Bats in forest remnants of the Cerrado savanna of eastern Mato Grosso, Brazil
}

\author{
Ricardo Firmino de Sousa ${ }^{1,2}$, Paulo Cesar Venere ${ }^{2,3}$ \& Karina de Cassia Faria ${ }^{1,2,4}$ \\ ${ }^{1}$ Departamento de Ciências Biológicas, Universidade do Estado de Mato Grosso - UNEMAT, \\ CEP 78690-000, Nova Xavantina, MT, Brazil. http://www.unemat.br \\ ${ }^{2}$ Programa de Pós-graduação em Ecologia e Conservação, Universidade do Estado de Mato \\ Grosso - UNEMAT, CEP 78690-000, Nova Xavantina, MT, Brazil. http://www.unemat.br/prppg/ppgec/ \\ ${ }^{3}$ Instituto de Ciências Biológicas e da Saúde, Universidade Federal de Mato Grosso - UFMT, \\ CEP 78698-000, Pontal do Araguaia, MT, Brazil. http://araguaia.ufmt.br \\ ${ }^{4}$ Corresponding author: Karina de Cassia Faria, e-mail: karinafaria@unemat.br
}

SOUSA, R.F., VENERE, P.C. \& FARIA, K.C. Bats in forest remnants of the Cerrado savanna of eastern Mato Grosso, Brazil. Biota Neotrop. 13(2): http://www.biotaneotropica.org.br/v13n2/en/abstract?inventory+ bn03313022013

\begin{abstract}
In the state of Mato Grosso, studies aiming to investigate the diversity and richness of bats are still scarce. In the present study, the chiropteran fauna of eastern Mato Grosso (Brazil) was investigated at four sites representing the Cerrado savanna biome with different degrees of anthropogenic impact, in the municipality of Nova Xavantina. Surveys were conducted between January and December, 2010, with a total of 48 nights of mist-netting. A total of 423 bats were captured, representing 25 species distributed in five families. A greater abundance of individuals was recorded at all sites during the rainy season, with considerable variation being observed over the course of the year in species richness and composition, and the abundance of bats. Species richness and bat abundance were higher in the better preserved habitats in comparison with the impacted areas. The timing of foraging activities appeared to vary among the specimens and there was a progressive increase in activity until 19:30 h, with a marked decline after 22:30 h. The ecological diversity (Shannon-Wiener index) of the bat community within the study area was $H^{\prime}=2.37$.
\end{abstract}

Keywords: Chiroptera, conservation, species richness, diversity.

SOUSA, R.F., VENERE, P.C. \& FARIA, K.C. Morcegos em remanescentes florestais de Cerrado do leste de Mato Grosso, Brasil. Biota Neotrop. 13(2): http://www.biotaneotropica.org.br/v13n2/pt/abstract?inventory + bn03313022013

Resumo: No estado de Mato Grosso, os estudos visando investigar a diversidade e riqueza de morcegos ainda são escassos. Neste estudo, a quiropterofauna da região leste mato-grossense foi investigada por meio de capturas em quatro áreas remanescentes de Cerrado com diferentes índices de conservação, no município de Nova Xavantina. As capturas ocorreram de janeiro a dezembro de 2010, totalizando 48 noites de amostragem. Foram capturados 423 indivíduos, distribuídos em 25 espécies e cinco famílias. Os quatro ambientes apresentaram maior abundância na estação chuvosa e, ao longo dos meses e entre as estações do ano a composição, riqueza e abundância de morcegos variaram. As áreas mais preservadas apresentaram maior riqueza e maior abundância de morcegos em relação às áreas degradadas. Foi possível verificar que o horário de forrageamento variou entre os espécimes capturados, ocorrendo um pico crescente de atividade até às 19:30h e uma redução acentuada por volta das 22:30h. A diversidade calculada pelo índice de Shannon-Wiener ( $\left.\mathrm{H}^{\prime}\right)$ para as áreas foi de $\mathrm{H}^{\prime}=2,37$.

Palavras-chave: Chiroptera, conservação, riqueza, diversidade. 


\section{Introduction}

The Cerrado biome occupies almost a quarter (23\%) of Brazilian territory (Ribeiro \& Walter 2008), and is composed of a mosaic of forests, savannas and grasslands, the distribution of which are determined primarily by relief, soils, and climatic factors, the interaction of which creates a considerable diversity of habitats (Sano 2011). The biological diversity of the Cerrado is also substantial, due in part to the size of biome, although this wealth of natural resources is poorly studied in general (Chaveiro et al. 2011).

At the present time, 101 bat species are known to occur in the Brazilian Cerrado, which corresponds to almost $60 \%$ of the total number of species found in Brazil. These species belong to 42 genera distributed in eight families - Emballorunidae, Noctilionidae, Mormoopidae, Phyllostomidae, Furipteridae, Vespertilionidae, Molossidae, and Thyropteridae. The family Phyllostomidae is the most diverse, with a total of 55 species, followed by the Molossidae, with 20 species, and the Vespertilionidae, with 12 (Paglia et al. 2012, Reis et al. 2013).

Few detailed studies of the bat fauna of Mato Grosso are available, which hampers any attempt to define the true diversity of the state's bat fauna (Gonçalves \& Gregorin 2004). Among the first surveys for the state are Pelzeln (1883) and Miranda-Ribeiro (1914), which recorded respectively 23 and 12 species. Up to now 84 bat species have been recorded in the state (Peracchi et al. 2011, Paglia et al. 2012, Reis et al. 2013), although these data are derived from widelyscattered localities, separated by extensive areas for which no data are available whatsoever.

In fragmented landscapes, bat communities tend to decline in abundance and species richness, and suffer considerable modifications of species composition. In particular, species with relatively restricted geographic ranges that are relatively intolerant of habitat disturbance tend to decline and disappear under the effects of anthropogenic impacts (Granjon et al. 1996, Cosson et al. 1999). The present study analyzed the species composition and richness, and abundance of the bat species recorded in remnants of Cerrado of eastern Mato Grosso, Brazil, representing different degrees of habitat disturbance.

\section{Material and Methods}

The study area is located in the municipality of Nova Xavantina, in eastern Mato Grosso. This region corresponds to a transition zone between the Cerrado and Amazon Forest domains. Vegetation is predominantly Cerrado intercalated with extensive tracts of cerradão woodland and typical Amazon forest (Marimon-Junior \& Haridasan 2005). The local climate is of Köppen's $A w$ type, with a mean annual temperature of $24{ }^{\circ} \mathrm{C}$, and precipitation of approximately $1,500 \mathrm{~mm}$ (Silva et al. 2008). Nova Xavantina is considered to be a priority area for the conservation of the Cerrado, given the diversity of species found within its geographic limits (Cavalcanti 2002).

Four sites were selected for the collection of specimens in remnants of cerrado habitats characterized by different levels of anthropogenic impact (Figure 1): site 1 (14 $38^{\circ} 14^{\prime \prime} \mathrm{S}$ and 52 $21^{\prime}$ $49^{\prime \prime} \mathrm{W}$ ) is a relatively well-preserved area of cerradão woodland; site 2 $\left(14^{\circ} 40^{\prime} 23^{\prime}\right.$ 'S and $\left.52^{\circ} 19^{\prime} 31^{\prime \prime} \mathrm{W}\right)$ is an area of typical cerrado savanna with low levels of disturbance and partly surrounded by pastures; site $3\left(14^{\circ} 40^{\prime} 12^{\prime \prime} \mathrm{S}\right.$ and $\left.52^{\circ} 21^{\prime} 52^{\prime \prime} \mathrm{W}\right)$ is typical cerrado savanna in the vicinity of the Rio das Mortes, which is suffering increasing impact from agricultural settlements, and site 4 (14 $40^{\circ} 48^{\prime \prime} \mathrm{S}$ and $52^{\circ} 19^{\prime} 31^{\prime}$ W) is a highly degraded gallery forest surrounded by pastures and homesteads.

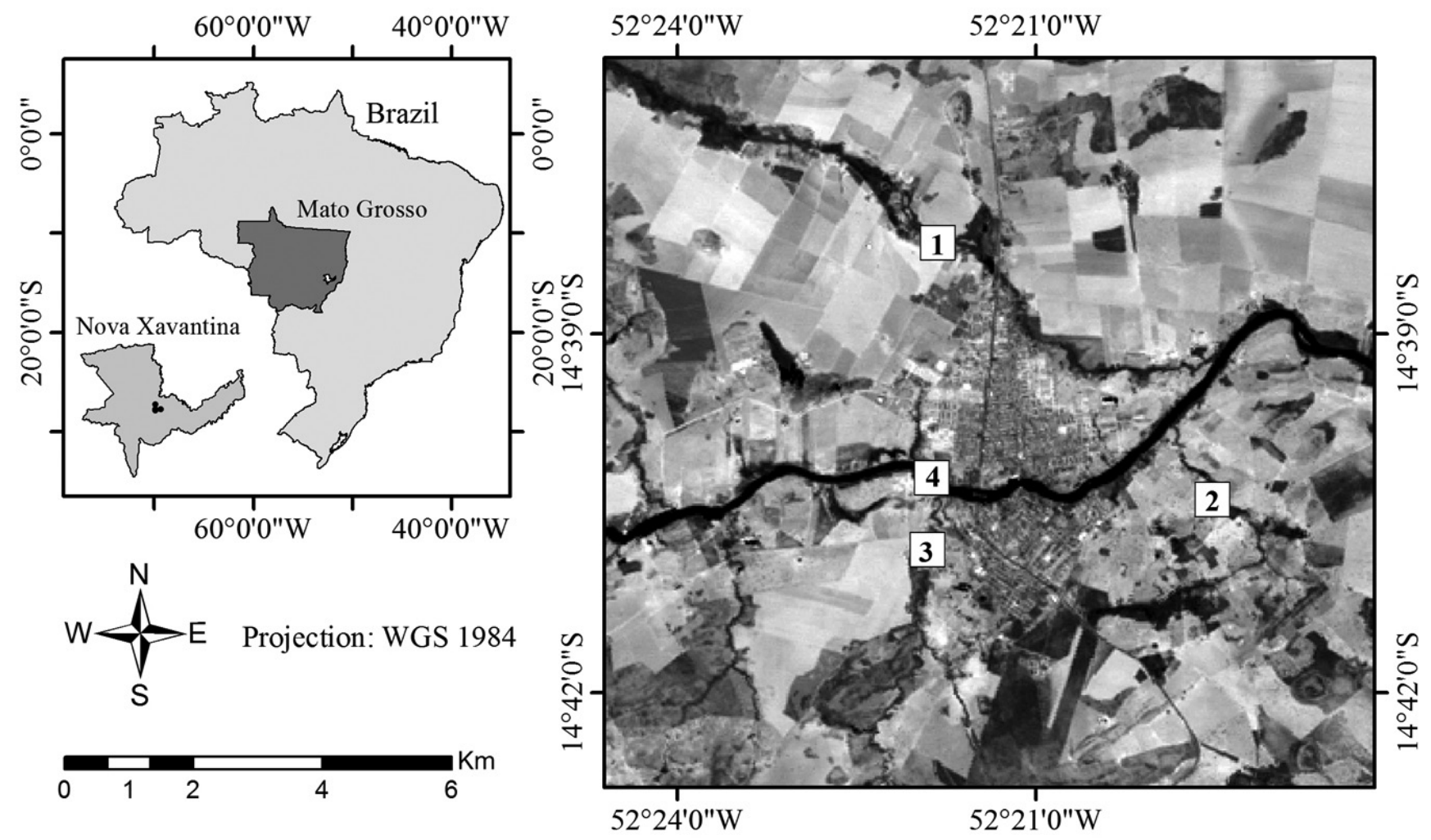

Figure 1. Map of the municipality of Nova Xavantina, state of Mato Grosso, showing the location of the four sites sampled. 1: Site 1 (14 ${ }^{\circ} 38^{\prime} 14^{\prime \prime} \mathrm{S}$ and

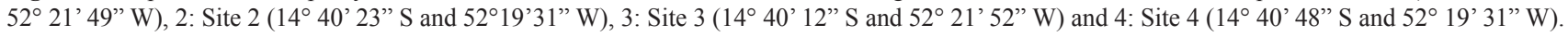


Twelve nights of sampling each site were performed between January and December, 2010, with a total of 48 nights of field work. Five mist-nets (four of $9 \mathrm{~m} \times 3 \mathrm{~m}$ and one $12 \mathrm{~m} \times 3 \mathrm{~m}$, with a $20 \mathrm{~mm}$ mesh) were used and they were set between 18:00 h and 24:00 h, and they were monitored at 30-minute intervals for the removal of captured bats, which were placed in cotton bags. The ambient temperature was measured during each visit with an analogical thermometer.

The bats captured in the mist-nets were identified based on the specialized literature, in particular Vizotto \& Taddei (1973), Eisenberg \& Redford (1999), Gregorin \& Taddei (2002) and Gardner (2007). The specimens that could not be identified were taken to the Nova Xavantina campus of the Mato Grosso State University (license number 18276-1 - IBAMA/SISBIO/MT) for examination in the Genetics Laboratory, and were deposited in this laboratory's chiropteran collection (collection numbers: RM 63-75; 80-86; 92-97; $102-108 ; 122-124 ; 131-137 ; 160-164 ; 181-183 ; 185-195 ; 205)$. In some cases, specialists were consulted in order to confirm the taxonomic identification of the specimens. Nomenclature was based on Paglia et al. (2012).

Species richness and abundance was computed for each site and season. The reliability of the estimates of species richness was evaluated using the Jackknife I richness estimator, run in the Estimates program (Colwell 2008). The Chi-square test $\left(X^{2}\right)$ was used to evaluate differences in the number of individuals captured in the rainy and dry seasons. The sampling effort was based on the proposal of Straube \& Bianconi (2002). Ecological diversity was estimated using the log-based Shannon-Wiener index, or $H^{\prime}$ (Krebs 1999). All analyses were run in Microsoft Office Excel 2007.

\section{Results}

During the study, a total of 423 bats were captured, representing 25 species belonging to five families (Table 1). The Phyllostomidae was the most diverse family, with a total of 18 species $(72 \%$ of the total captured), followed by the Molossidae, with three species $(12 \%)$, Vespertilionidae, with two species (8\%), and Emballorunidae and Mormoopidae with one species each (4\%).

Species richness and bat abundance were higher in the better preserved habitats (sites 1 and 2) in comparison with the impacted areas (sites 3 and 4). The largest number of individuals (158) was captured at site 1 , although the number of species (18) recorded at this site was only the second highest of the four sites. A total of 55 individuals was captured during the dry season, and 103 in the rainy season $\left(X^{2}=14.58\right.$, d.f. $\left.=1, P<0.001\right)$, with a predominance of females $(\mathrm{n}=89)$. The most abundant species were Carollia perspicillata (Linnaeus, 1758), with $36.7 \%$ of the specimens captured, Artibeus lituratus (Olfers, 1918), with 20.2\%, Platyrrhinus lineatus (E. Geoffroy, 1810), with 10.1\%, and Artibeus planirostris (Spix, 1823), with 7.6\%. Phyllostomus elongatus (E. Geoffroy, 1810) (one male and one female) and Vampyrum spectrum (Linnaeus 1758) (a male) were captured only at this site in the dry season.

The highest species richness (20 species) was recorded at site 2 , and the second highest number of individuals (96), of which, 34 were captured during the dry season, and 62 during the rainy season $\left(X^{2}=8.16\right.$, d.f. $\left.=1, P<0.005\right)$, once again with a predominance of females $(\mathrm{n}=58)$. The most abundant species were $A$. lituratus, with $20.8 \%$ of the individuals captured, A. planirostris, with $16.7 \%$, C. perspicillata, with $16.7 \%$, and Molossops temminckii (Burmeister, 1854), with 9.4\%. Six species were recorded only at this site - Chiroderma villosum Peters, 1860, Cynomops abrasus (Temminck, 1872), Lophostoma brasiliense Peters, 1866, Molossus molossus (Pallas, 1766), Uroderma bilobatum Peters, 1866, and Eptesicus diminutus Osgood, 1915. In all cases, one female was captured in the rainy season, except for $U$. bilobatum, with a male and female captured in the rainy season, and E. diminutus, with a female captured in the dry season.

Site 3 was characterized by the lowest species richness $(10$ species recorded), with 33 individuals captured during the dry season and 57 in the rainy season $\left(X^{2}=6.41\right.$, d.f. $\left.=1, P<0.01\right)$. In all, 56 females and 34 males were captured. The most abundant species were $A$. lituratus, with $36.7 \%$ of the individuals captured, Glossophaga soricina (Pallas, 1766), with $12.2 \%$, and C. perspicillata and P. lineatus, both with $11 \%$. One species - Rhynchonycteris naso (Wied-Neuwied, 1820) - was recorded only at this site, with three females and a male being captured during the dry season.

Site 4 was characterized by the second lowest species richness and the lowest abundance. Eleven species were recorded, with 27 individuals being captured in the dry season, and 52 in the rainy season $\left(X^{2}=7.91\right.$, d.f. $\left.=1, P<0.005\right)$, and once again, the majority of specimens were female $(\mathrm{n}=52)$. The most abundant species were $P$. lineatus, with $27.8 \%$ of the individuals captured, C. perspicillata and $A$. lituratus with $20.2 \%$ each, and A. planirostris, with $12.7 \%$. None of the species were unique to this site.

Overall, A. lituratus $(\mathrm{n}=101)$ was the most abundant species, corresponding to $23.9 \%$ of the total number of individuals captured, followed closely by $C$. perspicillata $(\mathrm{n}=100$ or $23.6 \%)$, P. lineatus with $12.5 \%$ of the total $(\mathrm{n}=53)$, A. planirostris with $11.1 \%(\mathrm{n}=47)$, and $G$. soricina, with $7.3 \%(\mathrm{n}=31)$ (Table 1). Together, these species represent $78.5 \%(n=332)$ of the total number of individuals captured. Of the other species, which accounted for $21.5 \%$ of the records $(\mathrm{n}=91)$, did not exceed 17 individuals (Table 1).

Total sampling effort for the four sites was $41,472 \mathrm{~m}^{2} . \mathrm{h}$. The number of species recorded during the first six months of the study period accumulated rapidly to 17 , that is, with half of the total sampling effort $\left(20,736 \mathrm{~m}^{2} . \mathrm{h}\right)$. A further eight species were added to the inventory during the second half of the study, including three (C. villosum, M. molossus, and U. bilobatum) in the last three months, when more than $83 \%$ of the total sampling effort had been completed. Estimated species richness by Jackknife I was 32.3 species, which indicates that only around $77.3 \%$ of the species that occur within the study area may have been captured during the study. The cumulative species curve did reach the asymptote (Figure 2).

During the dry season (April to September), a total of 149 individuals representing 16 species were captured, increasing to 274 individuals and 20 species during the rainy season (October-

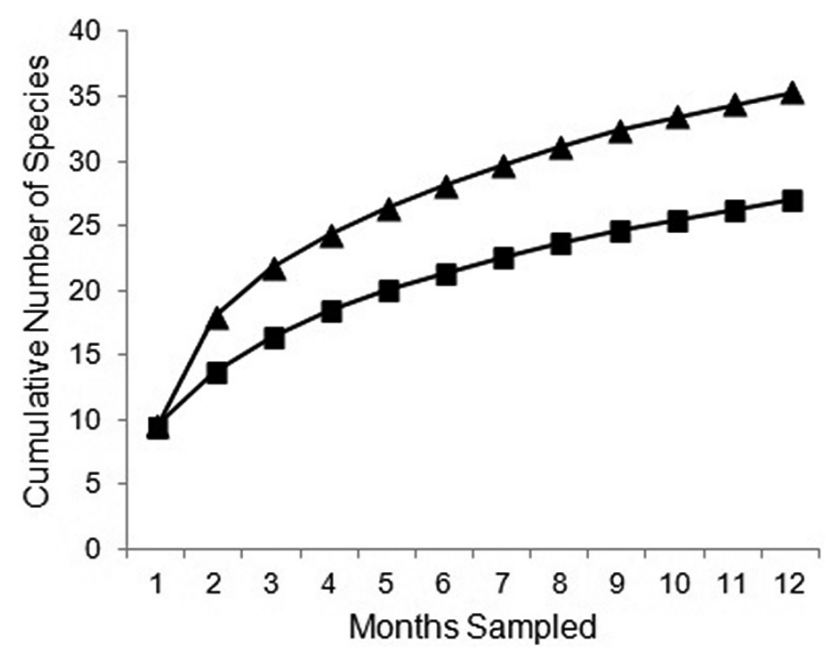

Figure 2. Accumulation curve of bats species ( $\boldsymbol{\Xi})$ calculated using sampling effort employed during the period of capture and estimated richness $(\boldsymbol{\Delta})$ by nonparametric Jackknife 1 estimator, between January and December 2010, at four sites representing the Cerrado savanna de Nova Xavantina, Mato Grosso. 
March). Twelve species were recorded in both seasons, whereas eight were captured only during the rainy season, and five during the dry season (Table 1).The number of specimens captured increased progressively to peak at 19:30 $\mathrm{h}$, and then oscillated before declining after 22:30 h (Figure 3).

Shannon-Wiener's diversity index $\left(H^{\prime}\right)$ for the study area as a whole was $H^{\prime}=2.37$. Site 1 presented the highest diversity $\left(H^{\prime}=2.40\right)$, while the other sites were considerably less diverse, and also more similar to one another (site $2: H^{\prime}=2.10$; site $3: H^{\prime}=2.03$; site 4: $H^{\prime}=2.08$ ).

\section{Discussion}

Inventories of bats in a number of different areas of the Cerrado have recorded between 11 and 25 species (Willig 1983, Gonçalves \& Gregorin 2004, Bordignon 2006, Anacleto et al. 2008, Camargo et al. 2009, Bezerra \& Marinho-Filho 2010, Ferreira et al. 2010, Zortéa et al. 2010, Silva \& Anacleto 2011). The number of species recorded in the present study represents $26.2 \%$ of the total known to occur in the Cerrado biome, and $29.8 \%$ of those recorded in Mato Grosso (Peracchi et al. 2011).

A relatively high abundance of $A$. lituratus, $C$. perspicillata, $P$. lineatus, and $G$. soricina was also recorded at a Cerrado site in Mato Grosso by Gonçalves \& Gregorin (2004). Similar results were obtained in Cerrado in Minas Gerais by Knegt et al. (2005) and in Mato Grosso do Sul by Ferreira et al. (2010). In the present study, there was a tendency for diversity to be lower at the more disturbed sites, although diversity at site 2 was similar to that of the disturbed sites, due to the marked abundance of $C$. perspicillata and A. lituratus, which together accounted for $56 \%$ of the individuals captured.

Eight species (A. lituratus, A. planirostris, C. perspicillata, M. temminckii, G. soricina, L. silvicolum, P. hastatus and P. lineatus) occurred at all four sites, indicating their generalist habits, which enable them to adapt to the different conditions found within the study area. Of these species, only L. silvicolum is thought to have a preference for well-preserved habitats (Nogueira et al. 2007b), while the other species are known to inhabit forest formations,

Table 1. Bat species and number of captured individuals in the four sites sampled in remnants of the Cerrado savanna, in the municipality of Nova Xavantina, state of Mato Grosso, in the rainy season (R) and dry season (D).

\begin{tabular}{|c|c|c|c|c|c|c|c|c|c|c|}
\hline \multirow{3}{*}{ Family/ Subfamily/ Species } & \multicolumn{8}{|c|}{ Sites } & \multirow{3}{*}{ Total } & \multirow{3}{*}{$\begin{array}{c}\text { Frequency } \\
\%\end{array}$} \\
\hline & \multicolumn{2}{|c|}{1} & \multicolumn{2}{|c|}{2} & \multicolumn{2}{|c|}{3} & \multicolumn{2}{|c|}{4} & & \\
\hline & $\mathbf{R}$ & D & $\mathbf{R}$ & D & $\mathbf{R}$ & D & $\mathbf{R}$ & D & & \\
\hline \multicolumn{11}{|l|}{ Emballorunidae } \\
\hline Rhynchonycteris naso (Wied-Neuwied, 1820) & - & - & - & - & - & 4 & - & - & 4 & 0.9 \\
\hline \multicolumn{11}{|l|}{ Molossidae } \\
\hline Cynomops abrasus (Temminck, 1826) & - & - & 1 & - & - & - & - & - & 1 & 0.2 \\
\hline Molossops temminckii (Burmeister, 1854) & 2 & 1 & 8 & 1 & 4 & - & 1 & - & 17 & 4.0 \\
\hline Molossus molossus (Pallas, 1766) & - & - & 1 & - & - & - & - & - & 1 & 0.2 \\
\hline \multicolumn{11}{|l|}{ Mormoopidae } \\
\hline Pteronotus parnellii (Gray, 1843) & - & 1 & - & 1 & - & - & - & - & 2 & 0.5 \\
\hline \multicolumn{11}{|l|}{ Phyllostomidae } \\
\hline \multicolumn{11}{|l|}{ Desmodontinae } \\
\hline Desmodus rotundus (E. Geoffroy, 1810) & 5 & 4 & - & 1 & - & - & - & 1 & 11 & 2.6 \\
\hline \multicolumn{11}{|l|}{ Glossophaginae } \\
\hline Anoura caudifer (E. Geoffroy, 1818) & 1 & - & 1 & - & 2 & - & - & - & 4 & 0.9 \\
\hline Glossophaga soricina (Pallas, 1766) & 2 & 5 & 3 & 4 & 4 & 7 & 1 & 5 & 31 & 7.3 \\
\hline Lonchophylla sp. Thomas, 1903 & 1 & - & - & - & - & - & 1 & - & 2 & 0.5 \\
\hline \multicolumn{11}{|l|}{ Phyllostominae } \\
\hline Lophostoma brasiliense Peters, 1866 & - & - & 1 & - & - & - & - & - & 1 & 0.2 \\
\hline Lophostoma silvicolum d'Orbigny, 1836 & 1 & 1 & 1 & - & 4 & - & - & 2 & 9 & 2.1 \\
\hline Phyllostomus discolor Wagner, 1843 & - & 1 & - & - & - & - & - & - & 1 & 0.2 \\
\hline Phyllostomus elongatus (E. Geoffroy, 1810) & 2 & - & - & - & - & - & - & - & 2 & 0.5 \\
\hline Phyllostomus hastatus (Pallas, 1767) & 3 & 2 & 1 & - & 2 & 1 & 3 & - & 12 & 2.8 \\
\hline Vampyrum spectrum (Linnaeus, 1758) & - & 1 & - & - & - & - & - & - & 1 & 0.2 \\
\hline \multicolumn{11}{|l|}{ Carollinae } \\
\hline Carollia perspicillata (Linnaeus, 1758) & 34 & 24 & 8 & 8 & 7 & 3 & 12 & 4 & 100 & 23.6 \\
\hline \multicolumn{11}{|l|}{ Sternodermatinae } \\
\hline Artibeus lituratus (Olfers, 1818) & 21 & 11 & 14 & 6 & 22 & 11 & 11 & 5 & 101 & 23.8 \\
\hline Artibeus planirostris (Spix, 1823) & 12 & - & 14 & 2 & 8 & 1 & 9 & 1 & 47 & 11.1 \\
\hline Chiroderma villosum Peters, 1860 & - & - & 1 & - & - & - & - & - & 1 & 0.2 \\
\hline Platyrrhinus incarum (Thomas, 1912) & 3 & 1 & 2 & 2 & - & - & - & - & 8 & 1.9 \\
\hline Platyrrhinus lineatus (E. Geoffroy, 1810) & 14 & 2 & 3 & 2 & 4 & 6 & 14 & 8 & 53 & 12.5 \\
\hline Sturnira lilium (E. Geoffroy, 1810) & - & 1 & 1 & 5 & - & - & - & - & 7 & 1.7 \\
\hline Uroderma bilobatum Peters, 1866 & - & - & 2 & - & - & - & - & - & 2 & 0.5 \\
\hline \multicolumn{11}{|l|}{ Vespertilionidae } \\
\hline Eptesicus diminutus Osgood, 1915 & - & - & - & 1 & - & - & - & - & 1 & 0.2 \\
\hline \multirow[t]{2}{*}{ Myotis nigricans (Schinz, 1821) } & 2 & - & - & 1 & - & - & - & 1 & 4 & 0.9 \\
\hline & 103 & 55 & 62 & 34 & 57 & 33 & 52 & 27 & 423 & 100 \\
\hline
\end{tabular}




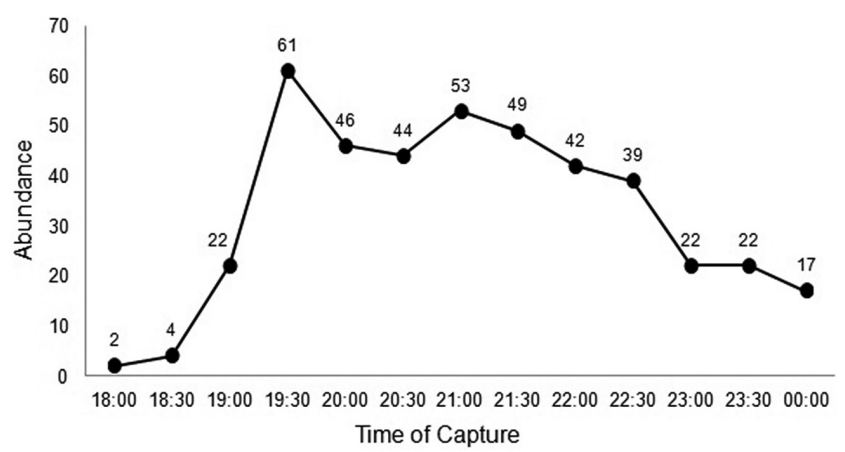

Figure 3. Number of bats captured at 30-minute intervals, during the six hours of exposure of the mist-nets in each of the 48 nights of field work, from January to December 2010, in remnants of the Cerrado savanna, in the municipality of Nova Xavantina, Mato Grosso.

tree holes, caves, and even urban areas (Ortêncio Filho et al. 2007, Nogueira et al. 2007a, b, Zortéa 2007).

Nine of the species recorded in the present study $(C$. villosum, C. abrasus, P. discolor, P. elongatus, L. brasiliense, Platyrrhinus incarum (Thomas, 1912), Pteronotus parnellii (Gray, 1843), Sturnira lilium (E. Geoffroy, 1810) and V. spectrum) were only captured in well-preserved habitats, that is, sites 1 and 2. P. discolor and S. lilium have been recorded in anthropogenic habitats (Evelyn \& Styles 2003, Nogueira et al. 2007b). The other seven species are all found in primary or secondary forest (Reis \& Peracchi 1987), where they may roost in tree holes and crowns, palm leaves, and cracks in rocks (Fabián \& Gregorin 2007, Nogueira et al. 2007a, b, Zortéa 2007). The only species found exclusively in anthropogenic habitats was $R$. naso, although this does not appear to reflect a preference for disturbed environments, but may simply be related to the tendency for the species to be found near bodies of water (Peracchi \& Nogueira 2007 ), given that site 3 , where the species was captured, is close to the Rio das Mortes.

In the Cerrado, resources such as fruit and insects tend to increase in abundance with the onset of the rainy season (Marinho-Filho \& Sazima 1998). The seasonal pattern in bat diversity and abundance recorded in the present study is typical of areas with well-defined seasons (Pedro \& Taddei 1997). Bats were especially abundant between October and December, when feeding resources (fruit, nectar, and insects) tend to be more available in the Cerrado (Ribeiro \& Walter 2008). Sipinski \& Reis (1995), Knegt et al. (2005), Zanon \& Reis (2007), and Tomaz \& Zortéa (2008) all recorded an increased abundance of bats in the rainy season.

The peak of activity observed during the first hours of the nocturnal period (and the subsequent decline in captures) in the present study is typical of the pattern recorded in most other studies, such as those of Reis (1981), Marques (1985), Reis \& Peracchi (1987), Sipinski \& Reis (1995) and Zanon \& Reis (2007). The activity pattern of bats is related primarily to their foraging behavior, although other factors may also be important, such as the reproductive or social status of the individual, as well as intra- and inter-specific competition for feeding resources (Fleming et al. 1972). Esbérard (2003) concluded that $H^{\prime}=2.0$ was a typical value for the Shannon-Wiener index for bat communities in the Neotropical region. The value recorded in Nova Xavantina $\left(H^{\prime}=2.37\right)$ is, as expected for the region, higher than the results of surveys of southern portions of the biome (Bordignon 2006, Zortéa \& Alho 2008, Camargo et al. 2009, Ferreira et al. 2010, Zortéa et al. 2010). Gregorin et al. (2011) recorded $H^{\prime}=2.86$ in preserved areas of the northern Cerrado.
The data obtained in this study, which had focused on forest remnants of Cerrado, characterized by different degrees of habitat disturbance, demonstrates the importance of preserved environments in maintaining the bat fauna of the region and contribute to the knowledge of the bats in the eastern portion of the state of Mato Grosso. However, knowledge about the bat fauna of Mato Grosso is still incipient and future studies in different areas and biomes of the state may significantly increase the species richness for the Mato Grosso.

\section{Acknowledgements}

The authors wish to thank FAPEMAT (Fundação de Amparo à Pesquisa do Estado de Mato Grosso) and CAPES (Coordenação de Aperfeiçoamento de Pessoal de Nível Superior) for financial support. The biologists Carlos Kreutz, Giovana Zilli and Yulie Shimano for their help in fieldwork .

\section{References}

ANACLETO, T.C.S., SANTOS, D.L.S.M. \& KÖPPE, V.C. 2008. Inventário da mastofauna da planície de inundação do Rio das Mortes, MT. In Fauna e Flora da planície da inundação do Rio das Mortes - MT (H.S.R. Cabette, ed.). Unemat, Nova Xavantina, p.81-88.

BEZERRA, A.M.R. \& MARINHO-FILHO, J. 2010. Bats of the Paranã River Valley, Tocantins and Goiás states, Central Brazil. Zootaxa 2725:41-56.

BORDIGNON, M. 2006. Diversidade de morcegos (Mammalia, Chiroptera) do Complexo Aporé-Sucuriú, Mato Grosso do Sul, Brasil. Rev. Bras. Zool. 23(4):1002-1009. http://dx.doi.org/10.1590/S010181752006000400004

CAMARGO, G., FISCHER, E., GONÇALVES, F., FERNANDES, G. \& FERREIRA, S. 2009. Morcegos do Parque Nacional da Serra da Bodoquena, Mato Grosso do Sul, Brasil. Chirop. Neotrop. 15(1):417-424.

CAVALCANTI, R.B. 2002. Cerrado e Pantanal. In Biodiversidade Brasileira: Avaliação e identificação de áreas e ações prioritárias para a conservação, utilização sustentável e repartição dos benefícios da biodiversidade nos biomas brasileiros (C.M. Maury, ed.). MMA/SBF, Brasília, p.55-64.

CHAVEIRO, E.F., SILVA, L.G. \& LIMA, S.C.O. 2011. Cerrado na perspectiva dos povos indígenas de Goiás: A arte da vida do povo Tupuia do CarretãoGO. Cienc. Cult. 3(1):39-41.

COLWELL, R.K. 2008. Estimates: Statistical estimation of species richness and shared species from samples. version 8.0. http://www.purl.oclc.org/ estimates.

COSSON, J., PONS, J. \& MASSON, D. 1999. Effects of forest fragmentation on frugivorous and nectarivorus bats in French Guiana. J. Trop. Ecol. 15(4):515-534. http://dx.doi.org/10.1017/S026646749900098X

EISENBERG, J.F. \& REDFORD, K.H. 1999. Mammals of the Neotropics: The Central Neotropics. University of Chicago Press, Chicago.

ESBÉRARD, C.E.L. 2003. Diversidade de morcegos em área de Mata Atlântica regenerada no sudeste do Brasil. Rev. Bras. Zool. 5(2):189-200.

EVELYN, M.J. \& STILES, D.A. 2003. Roosting requirements of two frugivorous bats (Sturnira lilium and Artibeus intermedius) in fragmented Neotropical forest. Biotropica 35(3):405-418.

FABIÁN, M.E. \& GREGORIN, R. 2007. Família Molossidae. In Morcegos do Brasil (N.R. Reis, A.L. Peracchi, W.A. Pedro \& I.P. Lima, eds). Nélio R. dos Reis, Londrina, p.149-166.

FERREIRA, C.M.M., FISCHER, E. \& PULCHÉRIO-LEITE, A. 2010. Fauna de morcegos em remanescentes urbanos de Cerrado em Campo Grande, Mato Grosso do Sul. Biota Neotrop. 10(3):155-160. http:// www.biotaneotropica.org.br/v10n3/en/abstract?article+bn02910032010 (último acesso em 25/02/2013).

FLEMING, T.H., HOOPER, E.T. \& WILSON, D.E. 1972. Three Central American Bat Communities: Structure, Reproductive Cycles, and Movement Patterns. Ecology 53(4):556-569. http://dx.doi. org $/ 10.2307 / 1934771$ 
GARDNER, A.L. 2007. Mammals of South America: Marsupials, Xenarthrans, Shrews, and Bats. The University of Chicago Press, Chicago and London.

GONÇALVES, E. \& GREGORIN, R. 2004. Quirópteros da Estação Ecológica da Serra das Araras, Mato Grosso, Brasil, com o primeiro registro de Artibeus gnomus e A. anderseni para o Cerrado. Lundiana 5(1):143-149.

GRANJON, L., COSSON, J.F., JUDAS, J. \& RINGUET, S. 1996. Influence of tropical rainforest fragmentation on mammal communities in French Guiana: early trends. Acta Ecol. 17(6):673-684.

GREGORIN, R. \& TADDEI, V.A. 2002. Chave artificial para a identificação de Molossídeos brasileiros (Mammalia, Chiroptera). J. Neotrop. Mammal. 9(1):13-32.

GREGORIN, R., GONÇALVES, E. AIRES, C.C. \& CARMIGNOTTO, A.P. 2011. Morcegos (Mammalia: Chiroptera) da Estação Ecológica Serra Geral do Tocantins: composição específica e considerações taxonômicas. Biota Neotrop. 11(1): http://www.biotaneotropica.org.br/v11n1/pt/ abstract?article+bn03811012011 (último acesso em 30/04/2013).

KNEGT, L.V., SILVA, J.A., MOREIRA, E.C. \& SALES, G.L. 2005. Morcegos capturados no município de Belo Horizonte, 1999-2003. Arq. Bras. Med. Vet. Zoo. 57(5):576-583. http://dx.doi.org/10.1590/S010209352005000500002

KREBS, C.J. 1999. Ecological Methodology. 2. ed. Benjamin/Cummings, New York.

MARIMON-JUNIOR, B.H. \& HARIDASAN, M. 2005. Comparação da vegetação arbórea e características edáficas de um cerradão e um cerrado sensu stricto em áreas adjacentes sobre solo distrófico no leste de Mato Grosso, Brasil. Acta Bot. Bras. 19(4):913-926. http://dx.doi.org/10.1590/ S0102-33062005000400026

MARINHO-FILHO, J. \& SAZIMA, I. 1998. Brazilian bats and conservation biology: a first survey. In Bat biology and conservation (T.H. Kunz \& P.A. Racey, eds). Smithsoniam Institution, Washington, p.282- 294.

MARQUES, S.A. 1985. Novos registros de morcegos do Parque Nacional da Amazônia (Tapajós), com observação do período de atividade noturna e reprodução. Bol. Mus. Paraense Emilio Goeldi, Ser. Zool. 2(1):71-83.

MIRANDA-RIBEIRO, A. 1914. Zoologia. Comissão de linhas telegráphicasestratégicas de Mato Grosso ao Amazonas. Hoehne, Rio de Janeiro.

NOGUEIRA, M.R., DIAS, D. \& PERACCHI, A.L. 2007a. Subfamília Glossophaginae. In Morcegos do Brasil (N.R. Reis, A.L. Peracchi, W.A. Pedro \& I.P. Lima, eds). Nélio R. dos Reis, Londrina, p.45-60.

NOGUEIRA, M.R., PERACCHI, A.L. \& MORATELLI, R. 2007b. Subfamília Phyllostominae. In Morcegos do Brasil (N.R. Reis, A.L. Peracchi, W.A. Pedro \& I.P. Lima, eds). Nélio R. dos Reis, Londrina, p.61-98.

ORTÊNCIO FILHO, H., LIMA, I.P. \& FOGAÇA, F.N.O. 2007. Subfamília Carolliinae. In Morcegos do Brasil (N.R. Reis, A.L. Peracchi, W.A. Pedro \& I.P. Lima, eds). Nelio R. dos Reis, Londrina, p.99-105.

PAGLIA, A.P., FONSECA, G.A.B., RYLANDS, A.B., HERRMANN, G., AGUIAR, L.M.S., CHIARELLO, A.G., LEITE, Y.L.R., COSTA, L.P., SICILIANO, S., KIERULFF, M.C.M., MENDES, S.L., TAVARES, V.C., MITTERMEIER, R.A. \& PATTON, J.L. 2012. Annotated Checklist of Brazilian Mammals. 2nd ed. Conservação Internacional do Brasil, Belo Horizonte.

PEDRO, W.A. \& TADDEI, V.A. 1997. Taxonomic assemblages of bats from Panga Reserve, Southeastern Brazil: abundance patterns and trophic relations in the Phyllostomidae (Chiroptera). Bol. Mus. Bio. Mello Leitão 6(3):3-21.

PELZELN, A. 1883. Brasiliche Saugethiere. Resultate von Johann Natterrer's Reisen in den Jahren 1817 bis 1835. Suppl, Vienna.
PERACCHI, A.L. \& NOGUEIRA, M.R. 2007. Família Emballorunidae. In Morcegos do Brasil (N.R. Reis, A.L. Peracchi, W.A. Pedro \& I.P. Lima, eds). Nélio R. dos Reis, Londrina, p.27-36.

PERACCHI, A.L., LIMA, I.P., REIS, N.R., NOGUEIRA, M.R. \& ORTENCIO FILHO, H. 2011. Ordem Chiroptera. In Mamíferos do Brasil (N.R. Reis, A.L. Peracchi, W.A. Pedro \& I.P. Lima, eds). Nelio R. dos Reis, Londrina, p.155-234.

REIS, N.R. 1981. Estudos ecológicos dos quirópteros de matas primárias e capoeiras da região de Manaus, Amazonas. Tese de Doutorado, Instituto Nacional de Pesquisas da Amazônia, Manaus.

REIS, N.R. \& PERACCHI, A.L. 1987. Quirópteros da região de Manaus, Amazonas, Brasil (Mammalia, Chiroptera). Bol. Mus. Paraense Emilio Goeldi, Ser. Zool. 3(2):161-182.

REIS, N.R., FREGONEZI, M.N., PERACCHI, A.L. \& SHIBATTA, O.A. 2013. Morcegos do Brasil: Guia de campo. Technical Books, Rio de Janeiro.

RIBEIRO, J.F. \& WALTER, B.M.T. 2008. As principais fitofisionomias do Bioma Cerrado. In Cerrado: Ecologia e Flora (S.M. Sano, S.P. Almeida \& J.F. Ribeiro, eds). Embrapa Cerrados, Brasília, p.151-212. PMid:18977172.

SANO, S.M. 2011. A oferta ambiental do Cerrado e seu uso. Cienc. Cult. 3(1):37-38.

SILVA, S.G. \& ANACLETO, T.C.S. 2011. Diversidade de morcegos entre áreas com diferente grau de alteração na área urbana do município de Nova Xavantina, MT. Chirop. Neotrop. 17(2):1003-1012.

SILVA, F.A.M., ASSAD, E.D. \& EVANGELISTA, B.A. 2008. Caracterização Climática do Bioma Cerrado. In Cerrado: Ecologia e Flora (S.M. Sano, S.P. Almeida \& J.F. Ribeiro, eds). Embrapa Cerrados, Brasília, p.69-88.

SIPINSKI, E.A.B. \& REIS, N.R. 1995. Dados ecológicos dos quirópteros da Reserva Volta Velha, Itapoá, Santa Catarina, Brasil. Rev. Bras. Zool. 12(3):519-528. http://dx.doi.org/10.1590/S010181751995000300006

STRAUBE, F.C. \& BIANCONI, G.V. 2002. Sobre a grandeza e a unidade utilizada para estimar esforço de captura com utilização de redes-deneblina. Chirop. Neotrop. 8(1):1-2.

TOMAZ, L.G. \& ZORTÉA, M. 2008. Composição faunística e estrutura de uma comunidade. In Ecologia de Morcegos (N.R. Reis, A.L. Peracchi \& G.A.S.D. Santos, eds). Technical Books, Rio de Janeiro, p.200-216.

VIZOTTO, L.D. \& TADDEI, V.A. 1973. Chave para determinação de quirópteros brasileiros. Rev. Facul. Fil. Cienc. Let. São José do Rio Preto - Bol. Cienc. 1:1-72.

WILLIG, M.R. 1983. Composition, microgeographic variation, and sexual dimorphism in Caatingas and Cerrado bat communities from Northeastern Brazil. Bull. Carnegie Mus. Nat. Hist. 23:1-131.

ZANON, C.M.V. \& REIS, N.R. 2007. Família Mormoopidae. In Morcegos do Brasil (N.R. Reis, A.L. Peracchi, W.A. Pedro \& I.P. Lima, eds). Nélio R. dos Reis, Londrina, p.129-132.

ZORTÉA, M. 2007. Subfamília Stenodermatinae. In Morcegos do Brasil (N.R. Reis, A.L. Peracchi, W.A. Pedro \& I.P. Lima, eds). Nélio R. dos Reis, Londrina, p.107-128.

ZORTÉA, M. \& ALHO, C.J.R. 2008. Bat diversity of a Cerrado habitat in Central Brazil. Biodivers. Conserv. 17(4):1-15. http://dx.doi.org/10.1007/ s10531-008-9318-3

ZORTÉA, M., MELO, F.R.,CARVALHO, J.C.\& ROCHA,Z.D. 2010. Morcegos da Bacia do rio Corumbá, Goiás. Chirop. Neotrop. 16(1):611-617. 